\title{
Penerapan Metode Prototype Pada Perancangan Sistem Pengarsipan Dokumen Kantor Kecamatan Lais
}

\author{
Kurniati ${ }^{1}$ \\ ${ }^{1}$ Teknik Informatika, Universitas Bina Darma, Palembang, Indonesia \\ Email: ${ }^{1}$ kurniati@binadarma.ac.id
}

\begin{abstract}
Abstrak
Arsip merupakan penghubung antara organisasi dengan organisai lain maupun seseorang dengan orang lain yang sifatnya penting dan rahasia. Begitupun pada Kantor Kecamatan Lais Kabupaten Musi Banyuasin sangat diharapkan proses pengelolaan arsip dapat dikelola dengan baik, cepat, dan mudah. Apabila arsip tidak dikelola dengan baik akan berdampak pada kesulitan menemukan informasi dan kehilangan data.Hal tersebut dapat menghambat tahapan pekerjaan selanjutnya. Dengan demikian dibutuhkan sebuah sistem basis data pengarsipan pada Kantor Kecamatan Lais menggunakan metode prototype untuk mengelola arsip secara tepat. Dengan teknik prototyping pengembang bisa membuat prototype terlebih dahulu sebelum mengembangkan sistem yang sebenarnya. Sehingga, pengembang akan dengan mudah mengetahui kebutuhan untuk pengembangan guna mendefinisikan objektif keseluruhan dari perangkat lunak yang akan dibangun sesui dengan kebutuhan objek. Sistem yang dibuat juga telah dilakukan pengujian dengan metode black box dan pengujian usability dari 30 responden menyatakan sistem berjalan baik berdasarkan hasil responden dengan rata-rata $89 \%$. Dengan adanya sistem ini sangat diharapkan dapat membantu pekerjaan pada kantor Kecamatan Lais dalam hal pengelolaan arsip secara baik dan tepat.
\end{abstract}

Kata Kunci: Arsip, Prototype, Black box

\section{PENDAHULUAN}

Sistem informasi memiliki peran penting di setiap instansi di era modern ini. Dimana perkembangannya sangat cepat dalam setiap aspek kehidupan tidak lepas dari peran perangkat komputer. Dalam suatu organisasi, arsip merupakan penghubung antara organisasi dengan organisai lain maupun seseorang dengan orang lain yang sifatnya penting dan rahasia. Terutama 


\section{Journal of Software Engineering Ampera}

Vol. 2, No. 1, February 2021 e-ISSN: 2775-2488

https://journal-computing.org/index.php/journal-sea/index

pada bagian pengarsipan dikarenakan pengarsipan merupakan ujung tombak dari sebuah informasi yang sangat berkualitas [1]. Dengan demikian, arsip harus dikelola dan disimpat secara baik dan aman. Kantor Kecamatan Lais di Kabupaten Musi Banyuasin saat ini masih menggunakan sistem manual dalam proses pengarsipan.

Dimana mereka masih mencatat menggunakan buku arsip, dan dokumen arsip disimpan didalam lemari atau tempat pengarsipan yang mana saat ini tidak lagi efektif dan efisien dari sisi waktu dan tempat dikarenakanakan dokumen arsip dari waktu kewaktu akan mengalami penambahan. Sehingga menimbulkan berbagai masalah terkait dengan tempat penyimpanan, biaya pemeliharaan, tenaga pengelola, fasilitas, ataupun faktor lain yang bisa menyebabkan kerusakan arsip [2]. Disamping itu akan menembah resiko terjadi kehilangan data tercecer, rusak bahkan hilang jika terjadi suatu bencana seperti kebakaran atau banjir. Agar kegiatan operasional dapat berjalan dengan efektif dan efisien maka dibutuhkan sistem pengelolaan dan manajemen yang baik dalam kegiatan pengarsipan [3]. Dimana informasi arsip surat tersebut dapat dipublikasi dan dikelola terlebih dahulu untuk menghindari kerancuan dalam pengelolaan informasi arsip surat [4].

Berdasarkan permasalahan di atas, maka peneliti ingin merancang sebuah sistem informasi pengarsipan dokumen berbasis web menggunakan metote prototype yang sesuai dengen kebutuhan di kantor Kecamatan Lais di Kabupaten Musi Banyuasin. Dengan adanya sistem informasi pengarsipan dokumen berbasis web ini diharapkan dapat membantu kinerja, mempercepat dalam proses pengarsipan dan arsip yang dimiliki dapat tersimpan dengan baik dan aman.

\section{METHODE}

Pada penelitian ini penulis menggunakan metode prototype untuk merancang sistem pengarsipan dokumen Kantor Kecamatan Lais di Kabupaten Musi Banyuasin. Prototyping merupakan teknik pengembangan sistem yang banyak digunakan dan teknik ini juga memberikan fasilitas bagi pengembang dan pemakai untuk saling berinteraksi selama proses pembuatan, sehingga pengembang dapat dengan mudah memodelkan perangkat lunak yang akan dibuat [5]. Prototyping melewati lima proses, yaitu communication, quick 


\section{Journal of Software Engineering Ampera}

Vol. 2, No. 1, February 2021 e-ISSN: 2775-2488

https://journal-computing.org/index.php/journal-sea/index

plan, quick design, prototype contruction dan delivery \& feedback seperti dijelaskan pada Gambar 1.

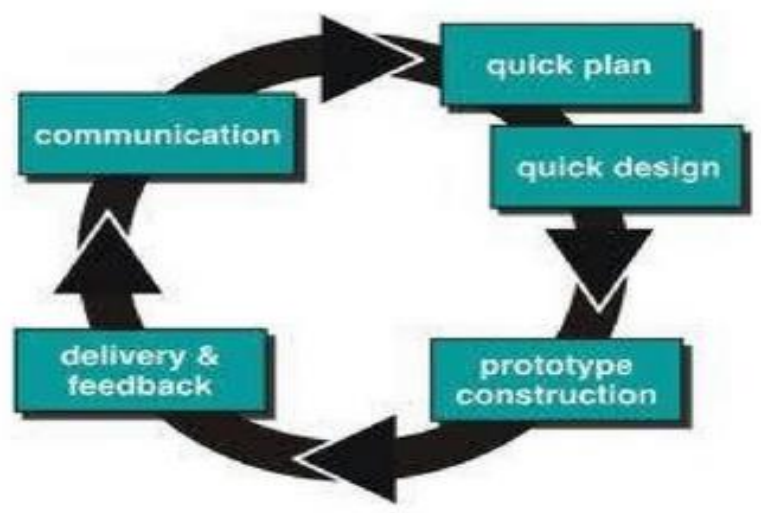

Gambar 1. Model Prototyping [6]

Proses-proses tersebut dapat dijelaskan seperti dibawah ini:

a. Communication, pada tahapan ini developer dan klien bertemu dan menentukan tujuan umum, kebutuhan yang diinginkan dan gambaran bagian-bagian yang akan dibutuhkan berikutnya.

b. Quick Plan, pada tahapan ini perancangan dilakukan cepat dan mewakili semua aspek software yang diketahui, dan rancangan ini menjadi dasar pembuatan prototype.

c. Modelling Quick Design, pada tahapan ini berfokus pada representasi aspek software yang bisa dilihat customer/user. Modelling Quick Design cenderung ke pembuatan prototype.

d. Construction of Prototype, membangun kerangka atau rancangan prototype dari software yang akan dibangun.

e. Delivery \& Feedback, prototype yang telah dibuat oleh developer akan disebarkan kepada user/klien untuk dievaluasi, kemudian klien akan memberikan feedback yang akan digunakan untuk merevisi kebutuhan software yang akan dibangun.

\section{HASIL DAN PEMBAHASAN}

Setelah penulis melakukan komunikasi dengan pihak pengelola arsip di Kantor Kecamatan Lais Kabupaten Musi Banyuasin dan beberapa tahap lainnya serta analisis data maka penelitian ini bertujuan menghasilkan sebuah sistem pengarsipan dokumen yang dapat membantu dalam pengelolaan dokumen 


\section{Journal of Software Engineering Ampera}

Vol. 2, No. 1, February 2021 e-ISSN: 2775-2488

https://journal-computing.org/index.php/journal-sea/index

arsip pada kantor Kecamatan Lais. Sistem ini dirancang untuk memaksimalkan pengelolaan dokumen arsip yang sebelumnya masih menggunakan metode manual atau konvensional. Sehingga akan menciptakan sebuah sistem yang akan dapat membantu pekerjaan menjadi efektif dan efisien baik dari sisi waktu, tenaga dan media penyimpanan serta yang terpenting adalah dari sisi keamanan data.

Pada tahap berikutnya penulis melakukan perancangan sistem pengarsipan dokumen berbasis web untuk kantor Kecamatan Lais Kabupaten Musi Banyuasin. Perancangan sistem ini meliputi use case diagram dan activity diagram untuk menjelaskan aktivitas yang terjadi pada sistem. Seperti yang pada Gambar 2, use case merupakan diagram yang bertujuan untuk menggambarkan seluruh aktifitas yang dilakukan oleh sistem dari sudut pandang penggunanya [7].

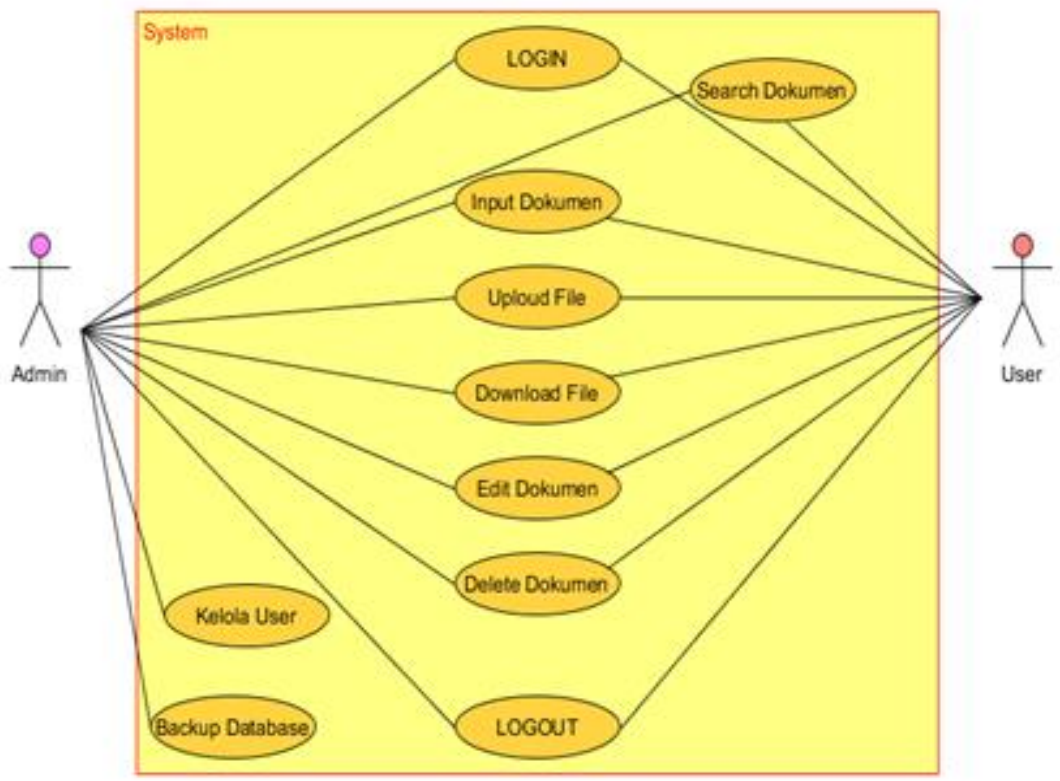

Gambar 2. Use Case Diagram

Sedangkan Gambar 3 dan Gambar 4 menjelaskan activity diagram yang merupakan diagram yang memperlihatkan aliran dari suatu aktivitas ke aktivitas lainnya dalam suatu sistem [8]. 


\section{Journal of Software Engineering Ampera}

Vol. 2, No. 1, February 2021 e-ISSN: 2775-2488

\section{https://journal-computing.org/index.php/journal-sea/index}

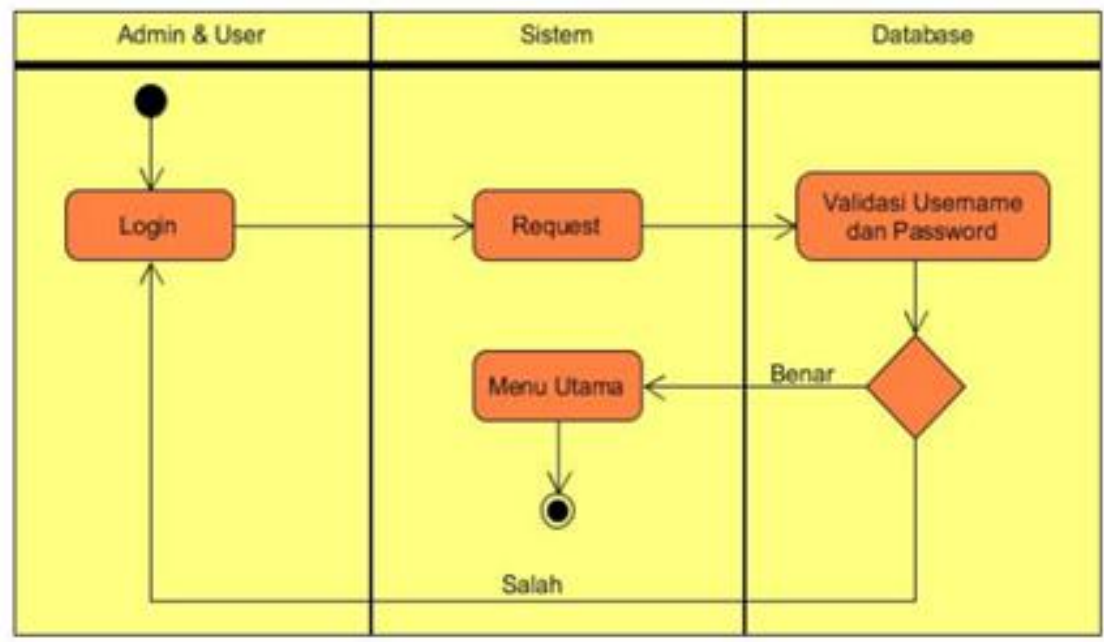

Gambar 3. Login Activity Diagram

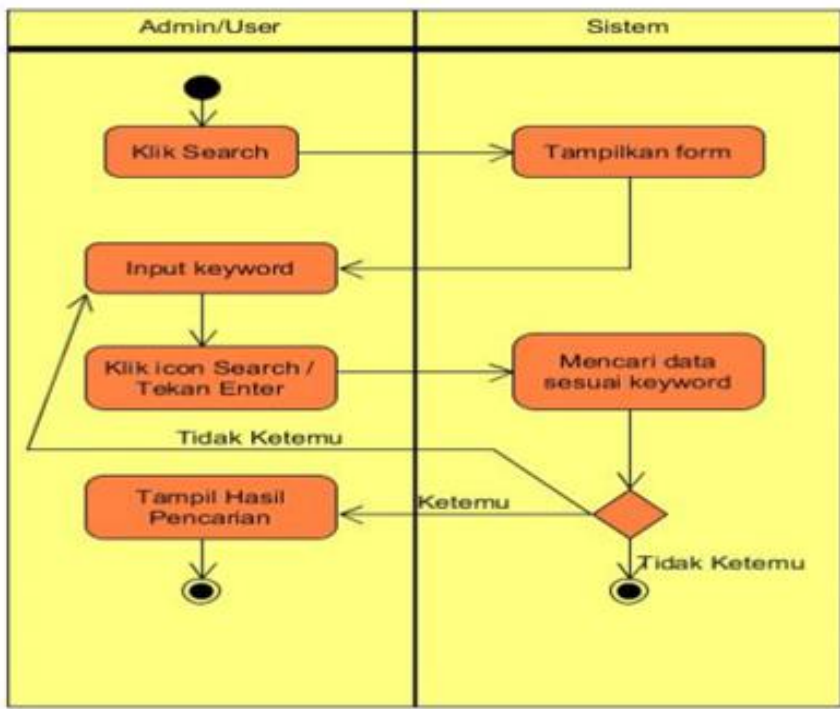

Gambar 4. Search Activity Diagram

Selanjutnya masuk ketahap desain sistem yang dapat dilihat pada Gambar 5, Gambar 6, Gambar 7, Gambar 8, Gambar 9, Gambar 10, Gambar 11 dan Gambar 12. 


\section{Journal of Software Engineering Ampera}

Vol. 2, No. 1, February 2021 e-ISSN: 2775-2488

\section{https://journal-computing.org/index.php/journal-sea/index}

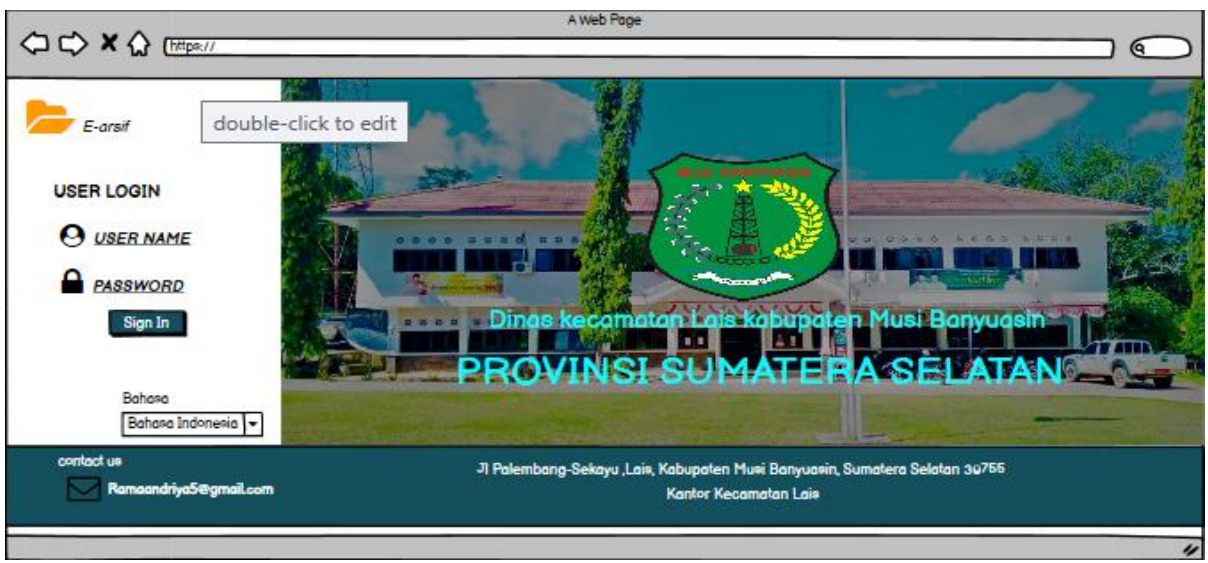

Gambar 5. Tampilan Login Sistem

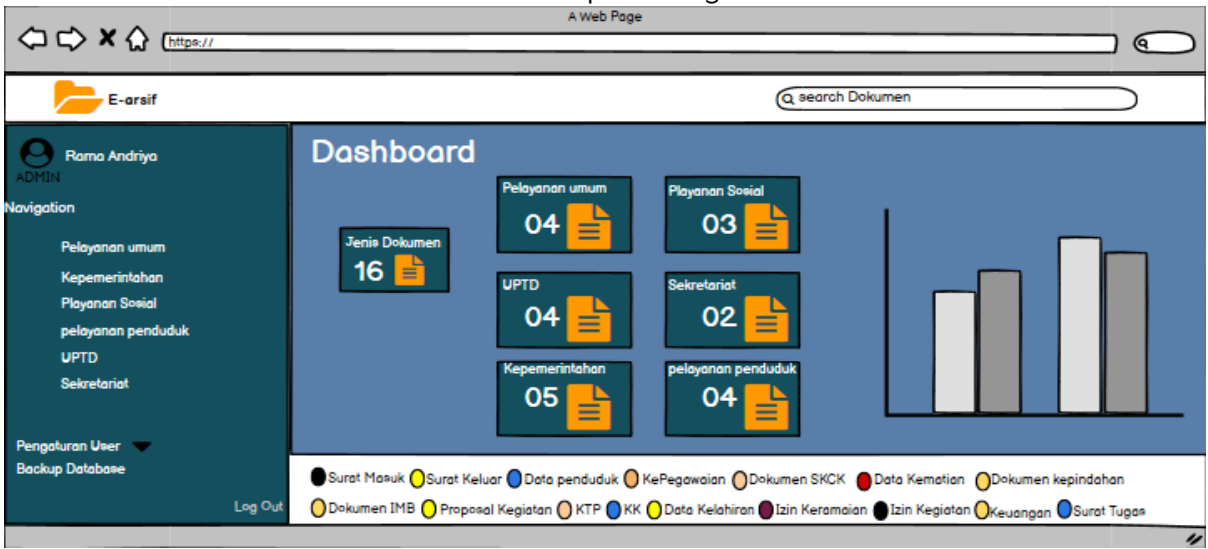

Gambar 6. Tampilan Dasboard

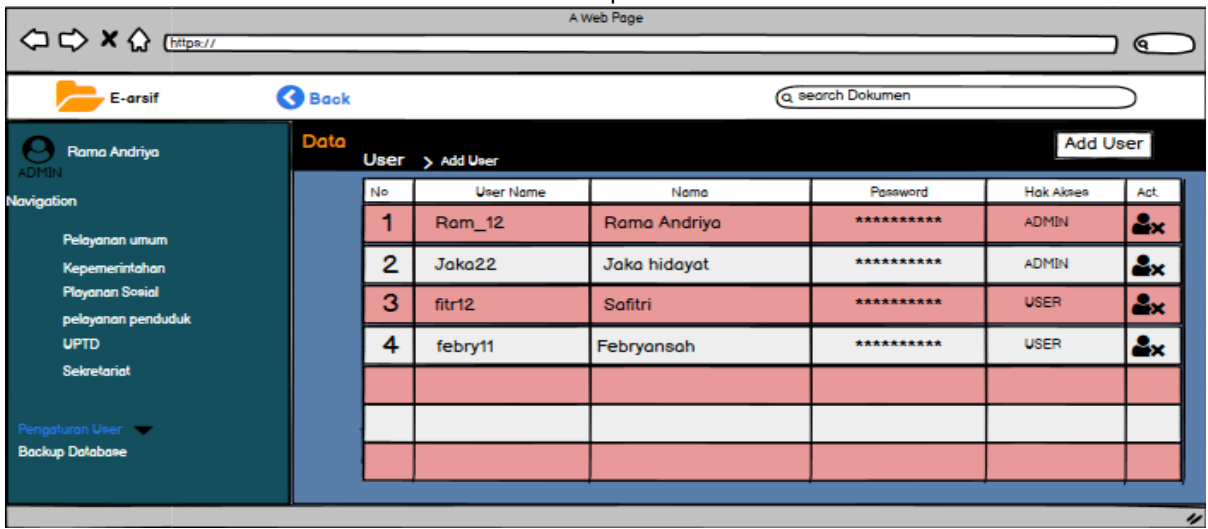

Gambar 7.Tampilan Kelola User 


\section{Journal of Software Engineering Ampera}

Vol. 2, No. 1, February 2021 e-ISSN: 2775-2488

\section{https://journal-computing.org/index.php/journal-sea/index}

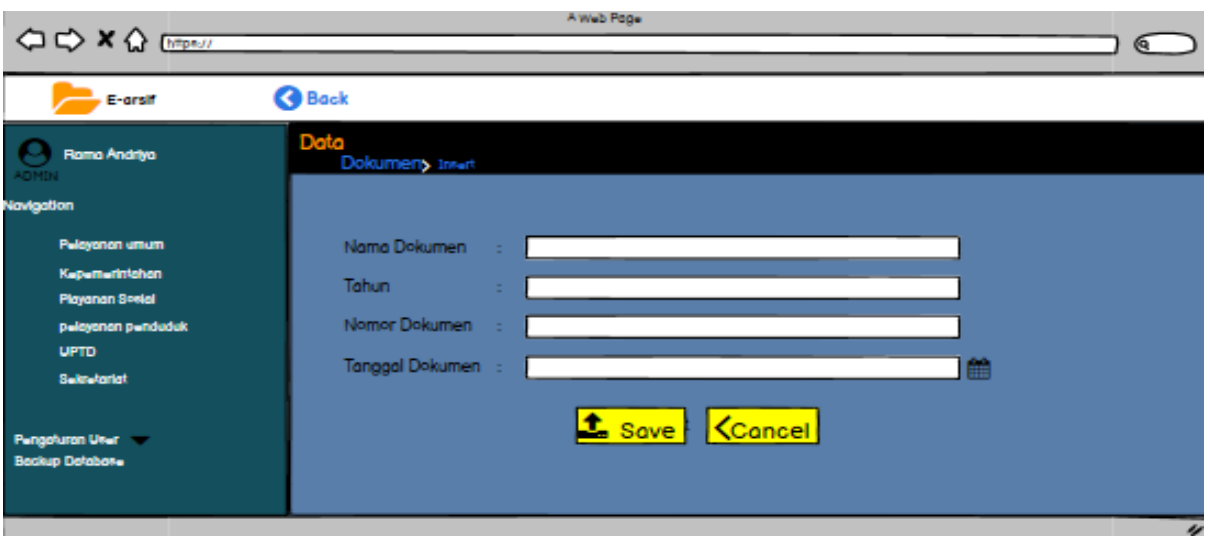

Gambar 8. Tampilan Menu Add Dokumen

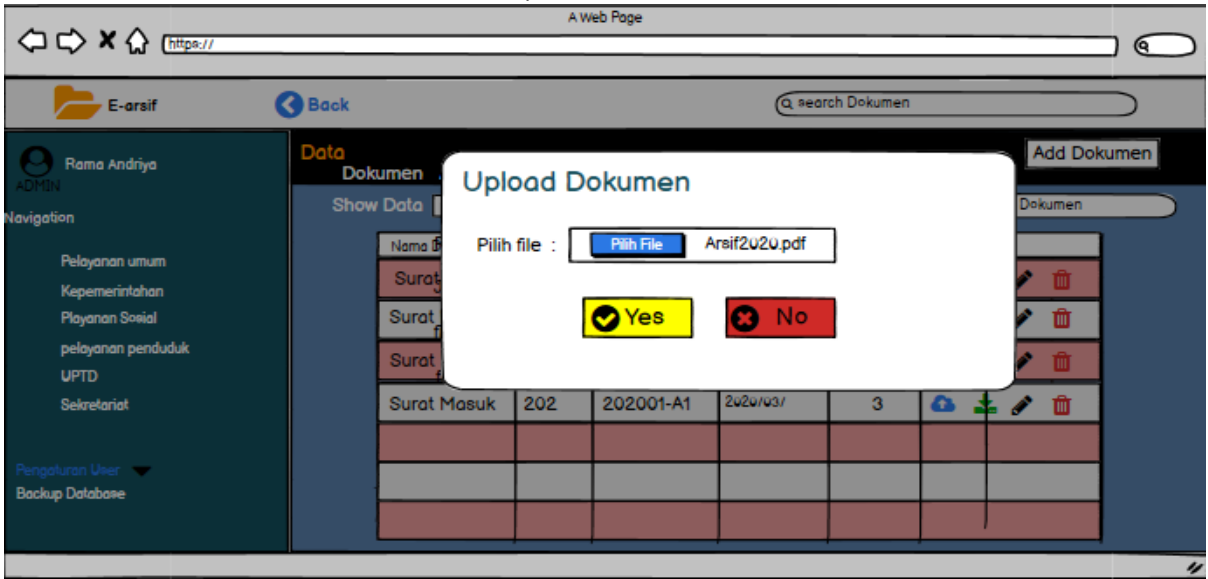

Gambar 9. Tampilan Menu Upload Dokumen

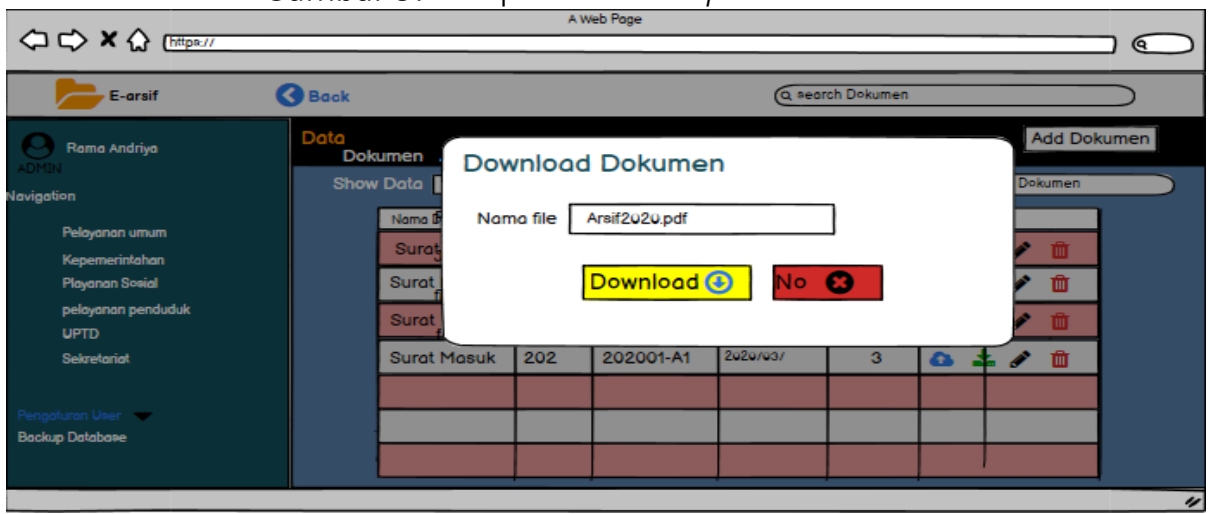

Gambar 10. Tampilan Menu Download Dokumen 


\section{Journal of Software Engineering Ampera}

Vol. 2, No. 1, February 2021 e-ISSN: 2775-2488

\section{https://journal-computing.org/index.php/journal-sea/index}

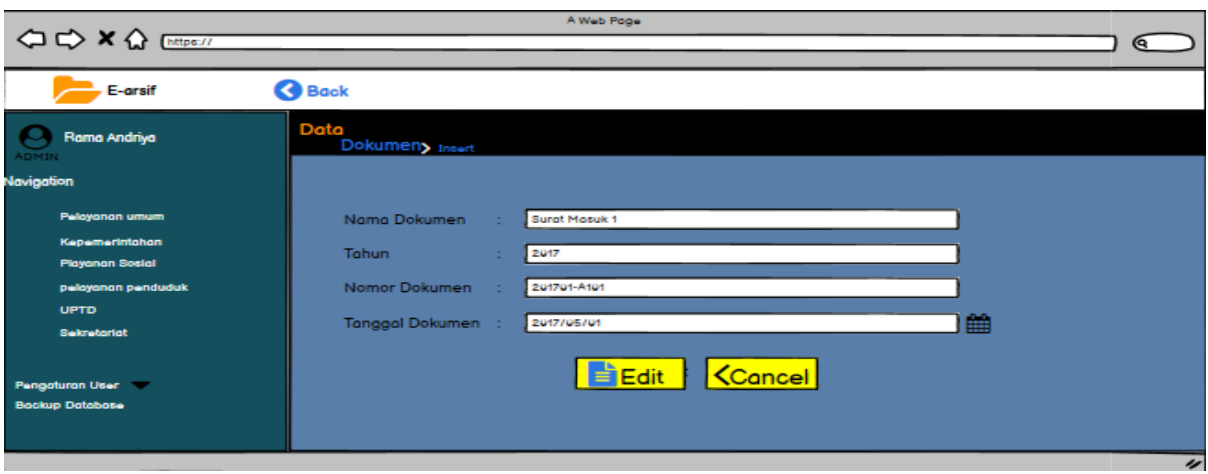

Gambar 11. Tampilan Menu Edit Dokumen

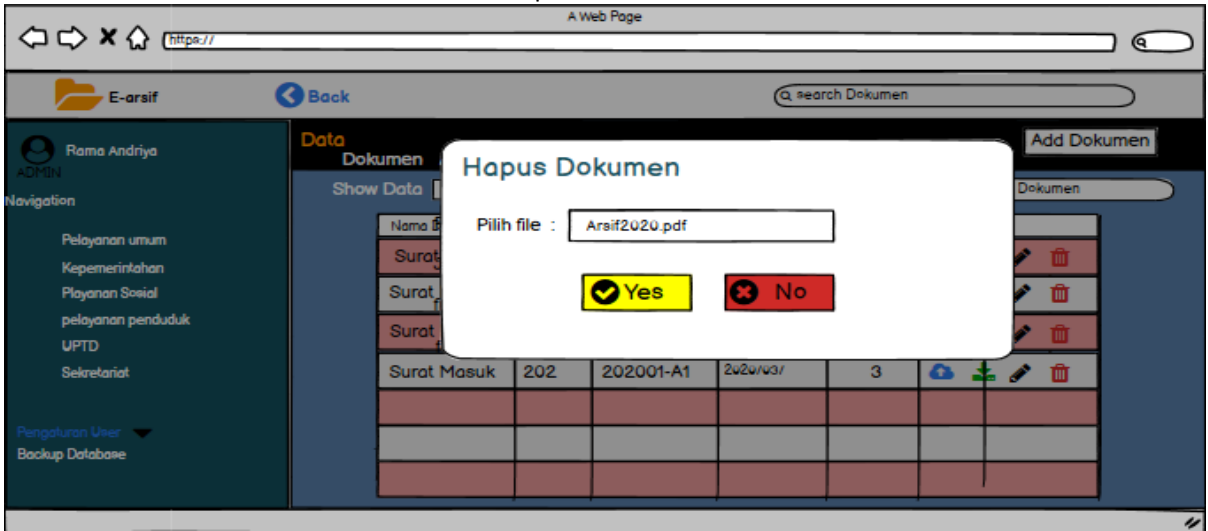

Gambar 12. Tampilan Menu Delete Dokumen

Tahap selanjutnya adalah tahapan evaluasi sistem. Diamana peneulias melakukan pengujian menggunakan uji blackbox dan uji usability. Uji blackbox adalah metode pengujian perangkat lunak yang menganalisis fungsionalitas perangkat lunak dengan membandingkan nilai input dengan nilai output [9] Hasil uji blackbox bertujuan untuk melihat apakah perancangan sistem informasi ini dapat diterima seperti yang diterangkan pada Tabel 1.

Tabel 1. Hasil Pengujian Black box

\begin{tabular}{lllll}
\hline No & Modul & Test & \multicolumn{1}{c}{$\begin{array}{l}\text { Hasil Yang } \\
\text { Diharapkan }\end{array}$} & Kesimpulan \\
\hline 1 & Login & $\begin{array}{l}\text { Memasukkan } \\
\text { username } \\
\text { password dan }\end{array}$ & Masuk ke halaman & Valid \\
& & & & \\
\hline
\end{tabular}


Journal of Software Engineering Ampera

Vol. 2, No. 1, February 2021 e-ISSN: 2775-2488

https://journal-computing.org/index.php/journal-sea/index

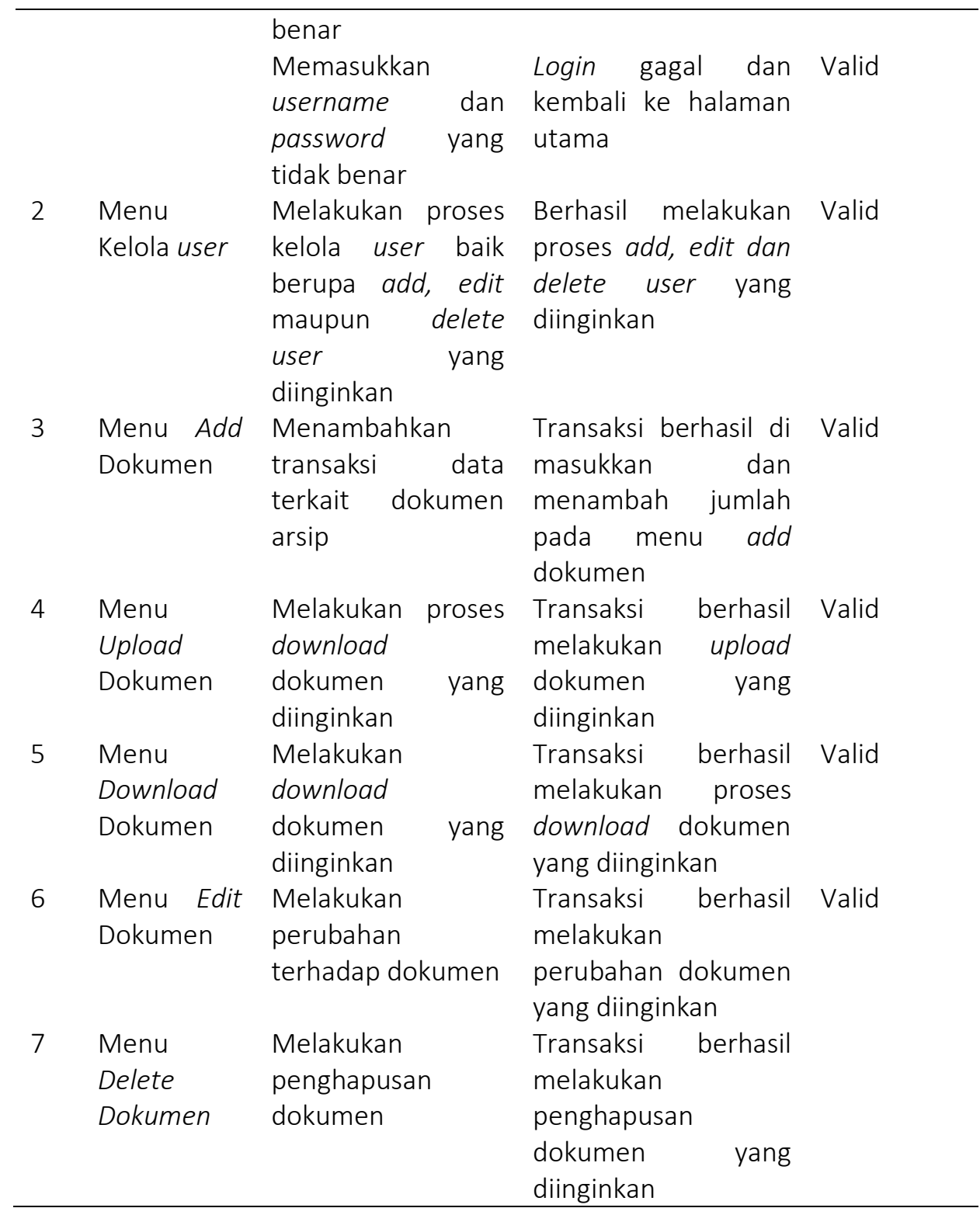

Uji usability dilakukan untuk melihat pendapat responden yang bertindak sebagai user terhadap sistem monitoring inventaris barang yang telah dibuat dapat digunakan. Dalam pengujian ini menggunakan 30 responden dengan 


\section{Journal of Software Engineering Ampera}

Vol. 2, No. 1, February 2021 e-ISSN: 2775-2488

https://journal-computing.org/index.php/journal-sea/index

melihat pendapat mereka yang dilihat berdasarkan pertanyaan yang telah disediakan berdasarkan dimensi learnability, effectiveness, memorability, error, dan satisfaction. User akan menilai pengalamannya menggunakan skala likert 1 (sangat tidak setuju), 2 (tidak setuju), 3 (Netral), 4 (setuju) dan 5 (sangat setuju). Hasil dari kusioner tersebut dapat dilihat pada Tabel 5.

Tabel 2. Persentase Jawaban Kuesioner Pengujian Usability

\begin{tabular}{|c|c|c|c|c|c|c|c|c|}
\hline \multicolumn{2}{|r|}{ Pertanyaan } & \multicolumn{5}{|c|}{ Responsi } & \multirow{2}{*}{$\begin{array}{l}\text { Jumlah } \\
\text { Respon } \\
\text { den }\end{array}$} & \multirow{2}{*}{$\begin{array}{c}\text { Persenta } \\
\text { se }\end{array}$} \\
\hline & & SS & $S$ & $N$ & TS & $\begin{array}{l}\text { ST } \\
\text { S }\end{array}$ & & \\
\hline P1 & $\begin{array}{l}\text { Semua fungsi dan menu } \\
\text { website ini berjalan } \\
\text { dengan baik }\end{array}$ & 12 & 15 & 3 & - & - & 30 & $86 \%$ \\
\hline P2 & $\begin{array}{lr}\text { Website ini } & \text { mudah } \\
\text { dimengerti } & \text { dan } \\
\text { mudah } & \text { untuk } \\
\text { digunakan } & \end{array}$ & 16 & 6 & 8 & - & - & 30 & $85 \%$ \\
\hline P3 & $\begin{array}{l}\text { Website ini memiliki } \\
\text { tampilan yang menarik }\end{array}$ & 12 & 13 & 5 & - & - & 30 & $85 \%$ \\
\hline P4 & $\begin{array}{l}\text { Website ini membantu } \\
\text { dalam pengolahan } \\
\text { data }\end{array}$ & 21 & 7 & 2 & - & - & 30 & $93 \%$ \\
\hline P5 & $\begin{array}{l}\text { Website ini dapat } \\
\text { mempercepat } \\
\text { pekerjaan petugas }\end{array}$ & 24 & 6 & - & - & - & 30 & $96 \%$ \\
\hline
\end{tabular}

Berdasarkan hasil pengujian Tabel 5 diperoleh hasil perhitungan persentase jawaban kuesioner dari 30 responden terhadap 5 pertanyaan adalah 86\% untuk pertanyaan website memiliki fungsi dan menu yang dapat berjalan dengan baik, 85\% untuk pertanyaan website mudah dimengerti dan mudah untuk digunakan, 85\% untk pertanyaan website ini memiliki tampilan yang menarik, 93\% terhadap pertanyaan keempat bahwa website ini membantu dalam pengolahan data dan $96 \%$ website ini dapat mempercepat pekerjaan petugas. 


\section{Journal of Software Engineering Ampera}

Vol. 2, No. 1, February 2021 e-ISSN: 2775-2488

https://journal-computing.org/index.php/journal-sea/index

\section{KESIMPULAN}

Berdasarkan dari pembahasan penulis dapat menarik kesimpulan sebagai berikut :

1. Sistem pengarsipan dokumen mampu memberikan kemudahan kepada petugas dan admin kantor Kecamatan Lais dalam mengelola dokumen arsip dengan baik serta lebih mudah dalam proses pencarian dan keamanan data lebih terjamin.

2. Berdasarkan hasil uji blackbox semua menu yang ada pada sistem berfungsi dengan baik sesui dengan fungsionalitas menu tersebut.

3. Berdasarkan hasil pengujian usability terhadap 30 responden menyatakan bahwa secar keseluruhan sistem dapat diterima pengguna dengan sangat baik, melalui indikasi ratarata persentase $89 \%$ pada pernyataan responden yang meliputi fungsi, menu, mudah dimengerti, mudah untuk digunakan, tampilan yang menarik, membantu pengolahan data, dan dapat mempercepat pekerjaan.

\section{DAFTAR PUSTAKA}

[1] S. Mahmudah and dkk, "Sistem Informasi Manajemen Pengarsipan Surat Masuk Dan Surat Keluar (Studi Kasus: Ma Darul Ihya Bogor)," JURNAL MEDIA INFORMATIKA BUDIDARMA, vol. 3, no. 3, pp. 225-231, 2019.

[2] M. . D. Irawan and S. A. Simargolang, "Implementasi E-Arsip Pada Program Studi Teknik Informatika," Jurnal Teknologi Informasi, vol. 2, no. 1, pp. 6784, 2018.

[3] R. A. Pascapraharastyan and dkk, "Rancang Bangun Sistem Informasi Manajemen Arsip Rumah Sakit Bedah Surabaya Berbasis Web," Jurnal Sistem Informasi, vol. 3, no. 1, pp. 139-143, 2014.

[4] E. Putra and dkk, "Perancangan Sistem Informasi Pengarsipan Surat Berbasis Web Di Kecamatan XYZ," Jurnal IKRA-ITH Informatika, vol. 4, no. 2, pp. 55-64, 2020.

[5] T. A. Kurniawan and Aditia, "Penerapan Metode Prototype Dalam Pengembangan Sistem Untuk Perancangan Aplikasi Web Jasa Restorasi 


\section{Journal of Software Engineering Ampera}

Vol. 2, No. 1, February 2021 e-ISSN: 2775-2488

https://journal-computing.org/index.php/journal-sea/index

Pada PT. QUANTUM NUSATAMA," Jurnal IImiah Fakultas Teknik LIMIT'S, vol. 13, no. 1, pp. 1-8, 2017.

[6] M. Prabowo, Metodologi Pengembangan Sistem Informasi, Salatiga: LP2M IAIN Salatiga, 2020.

[7] L. Rozana and R. Musfikar, "Analisis Dan Perancangan Sistem Informasi Pengarsipan Surat Berbasis Web Pada Kantor Lurah Desa Dayah Tuha," Jurnal Pendidikan Teknologi Informasi, vol. 4, no. 1, pp. 14-20, 2020.

[8] M. Muslihudin and Oktafianto, Analisi dan Perancangan Sistem Informasi Menggunakan Model Terstruktur dan UML, Yogyakarta: ANDI OFFSET, 2016.

[9] T.S.Jaya, "“Pengujian Aplikasi dengan Metode Blackbox Testing Boundary Value Analysis (Studi Kasus: Kantor Digital Politeknik Negeri Lampung)," Jurnal Informatika: Jurnal Pengembangan IT, vol. 3, no. 2, p. 45-46, 2018. 